\title{
Analisis Perbandingan Model Kesulitan Keuangan Studi Pada Bank Bukopin Tbk
}

\author{
Hisky Ryan Kawulur ${ }^{1}$ \\ Fakultas Ekonomi \\ Universitas Negeri Manado, Indonesia
}

Surel : kawulurhisky@unima.ac.id

\section{ABSTRAK}

Tujuan dari Penelitian ini untuk menganalisis dan membandingkan nilai prediksi model kesulitan keuangan Altman z-score dengan model Zmijewski. Metode penelitian yang digunakan adalah deskriptif kuantitatif dalam menjelaskan fenomena yang terjadi. Penelitian ini menggunakan data laporan keuangan bank Bukopin untuk tahun 2018, 2019 dan 2020. Analisis data dilakukan dengan cara menghitung rasio dari masing-masing model dari tahun 2018, 2019 dan 2020 selanjutnya hasil kriteria dari model altman z-score dan model zmijewski dibandingkan dan dianalisis sesuai dengan kriterianya. Hasil penelitian menunjukkan bahwa kedua model baik altman z-score maupun model zmijewski memberikan hasil yang sama yaitu pada tahun-tahun yang akan datang perusahan berpotensi untuk menghadapi kebangkrutan.

\section{Kata Kunci: Altman Z-Score; Zmijewski; Perbankan; Perbandingan Model. \\ Comparative Analysis of the Study on Financial Distress Model at Bank Bukopin Tbk}

\section{ABSTRACT}

The purpose of this study is to analyze and compare the predictive value of the Altman z-score model of financial distress with the Zmijewski model. The research method used is descriptive quantitative in explaining the phenomena that occur. This study uses data from Bukopin's financial statements for 2018, 2019 and 2020. Data analysis is carried out by calculating the ratio of each model from 2018, 2019 and 2020, then the results of the criteria from the altman $z$-score model and the zmijewski model are compared and analyzed according to the criteria. The results showed that both the Altman z-score model and the Zmijewski model gave the same results, namely in the years to come the company has the potential to face bankruptcy.

Keywords: Altman Z-Score; Zmijewski; Banking; Comparison Model.

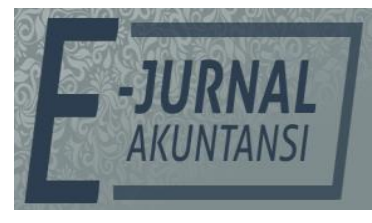

e-ISSN 2302-8556

Vol. 31 No. 6

Denpasar, Juni 2020

Hal. 1541-1548

DOI:

10.24843/EJA.2021.v31.i06.p15

PENGUTIPAN:

Kawulur, H.R. (2021).

Analisis Perbandingan

Model Kesulitan Keuangan

Studi Pada Bank Bukopin

Tbk. E-Jurnal Akuntansi, 31(6), 1541-1548

RIWAYAT ARTIKEL: Artikel Masuk: 7 April 2021 Artikel Diterima: 20 Juni 2021

Artikel dapat diakses : https://ojs.unud.ac.id/index.php/Akuntansi/index 


\section{PENDAHULUAN}

Pada awal tahun 2020 seluruh bangsa di dunia ini mengalami ancaman yang dikeranakan oleh virus corona, ancaman ini mengakibatkan masyarakat dunia mengadaptasi suatu kebiasaan baru yang membuat mereka melaksanakan berbagai macam protokol kesehatan. Virus corona/covid-19 merupakan virus yang mengancam kesehatan masyarakat dengan cara penularannya melalui bersin, batuk atau droplet. Virus ini bukan hanya mengancam kesehatan tetapi juga mengakibatkan penurunan tingkat ekonomi bagi seluruh bangsa di dunia termasuk di Indonesia.

Indonesia dihadapkan dengan suatu masa yang tidak pasti sehingga menghambat pengambilan keputusan yang lebih baik. Dampak sosial dan ekonomi yang terjadi akibat covid-19 membuat rencana pembangunan disesuaikan dengan keadaan yang ada (Muhyiddin, 2020). Data dari kementerian keuangan menunjukan pertumbuhan ekonomi menganami penurunan dari level 2,5 persen hingga 0 persen ini semua bisa terjadi jika tidak ada strategi yang tepat yang dilakukan oleh negara. (Hanoatubun, 2020).

Adapun berbagai macam sector yang mengalami dampak dari covid-19 seperti Industri, Konstruksi, Gas, Listrik, Pertambangan, Air bersih, Retail, Restoran dan Perhotelan. Hampir semua sector jasa mengalami penurunan kecuali pertanian peternakan, perikananan dan beberapa sector jasa yang lain mengalami kenaikan oleh musim panen. Secara global Pasar modal dan Surat Utang mengalami penurunan (Muliati, 2020) dan (Taufik \& Ayuningtyas, 2020)

Sektor keuangan termasuk perbankan mengalami penurunan yang serius akibat pandemi ini kemampuan tidak mampu membayar hutang oleh nasabah menyebabkan tingginya kredit bermasalah, biaya operasional yang terus meningkat, Pendapatan bunga dan kredit menurun, Capital adequacy ratio menurun, dan pendapatan bunga yang menurun merupakan beberapa dampak akibad Covid 19 (Asmoro, 2020) dan (Covid, 2020). Penurunan ini membuat perbankan mengalami kesulitan keuangan (financial distress). Kesulitan keuangan sendiri merupakan keadaan dimana perusahaan mengalami kesulitan akan kas dan tidak mampu membayar hutang, keadaan ini sering terjadi sebelum perusahaan mengalami kebangkrutan (Ashraf et al., 2019), (Geng et al., 2015), (Kansal, et al., 2019) dan (Zmijewski, 1984).

Terdapat berbagai macam model prediksi kesulitan keuangan yang sering digunakan dan masih dikatakan memberikan tingkat akurasi prediksi yang baik seperti altman z-score (Sajjan, 2016), (Utami \& Kawulur, 2020), (Udayana et al., 2013) dan (Jayanti \& Rustiana, 2015). Berbagai penelitian mendapati model altman dan zmijewski memberikan tingkat akurasi yang paling baik dari ketiga model (Ayu Damayanti et al., 2011), (Suparningsih \& Chaeriah, 2019), dan (Suryawardani, 2015). Terdapat juga penelitian yang mendapati bahwa model altman dan zmijeski tidak memberikan tiangkat akurasi yang baik (Jayanti \& Rustiana, 2015), (Permana et al., 2017), dan (Prasetianingtias \& Kusumowati, 2019)

Bank bukopin merupakan salah satu perbankan yang mengalami dampak kerugian yang lebih buruk akibat Covid-19 dibandingkan perbankan lain yang ada di Indonesia, ini dilihat dari laba perusahaan yang terus mengalami 
penurunan dari triwulan pertama sampai ketiga tahun 2020. Berikut data laporan laba rugi komprehensif tahun 2020.

Tabel 1. Jumlah Laba Rugi Komprehensif Bank Bukopin Tahun 2020

\begin{tabular}{|c|c|c|c|c|}
\hline \multirow{2}{*}{$\begin{array}{l}\text { Jumlah Laba/Rugi } \\
\text { Komprehensif }\end{array}$} & 31-Mar & 30-Jun & 30-Sep & 31-Dec \\
\hline & Rp166,088 & $\operatorname{Rp} 217,826$ & $(\operatorname{Rp} 873,136)$ & $(\mathrm{Rp} 3,041,719)$ \\
\hline
\end{tabular}

Sumber: idx.go.id, 2020

Tabel 1 menggambarkan bahwa bank bukopin mengalami kerugian sepanjang tahun 2020 dan ini disebabkan oleh dampak pandemic covid-19 yang membuat pendapatan atas kredit menurun sedangkan biaya operasional yang terus meningkat.

Penelitian ini menggunakan teori kesulitan keuangan untuk memprediksi kesehatan perusahaan. Perusahaan dapat dikategorikan mengalami kesulitan jika memiliki arus kas negatif, hutang yang akan jatuh tempo tidak mampu dibawayar dan fenomena ini sering terjadi sebelum perusahaan bangkrut (Brigham \& Daves, 2007). Kesulitan keuangan adalah kondisi penurunan kesehatan keuangan perusahaan yang terjadi sebelum perusahaan bangkrut (Plat \& Plat, 2002). Sedangkan suatu kondisi keuangan yang sangat parah dialami oleh perusahaan yang menyebabkan kegiatan operasional tidak bisa berjalan disebut kebangkrutan (Udayana et al., 2013). Jika jumlah nilai aset lancar kurang dari jumlah liabilitas atau ketika jumlah liabilitas jangka pendeknya melebihi nilai wajar asetnya kondisi tersebut bisa menyebabkan kegagalan keuangan atau kebangkrutan, perusahaan yang sudah tidak mempunyai dana untuk membiayai operasi bisnis bisa dikategorikan perusahaan yang mengalami kebangkrutan (Ali Abusalah Elmabrok \& Ng, 2012). Kebangkrutan dari perusahaan dapat berdampak buruk bagi perekonomian bangsa ataupun perekonomian global. Kegagalan perusahaan berdampak negatif kepada para pemangku kepentingan perusahaan.

Kesulitan keuangan terjadi sebelum terjadi kebangkrutan pada suatu perusahaan. Oleh sebab itu prediksi kesulitan keuangan diperlukan oleh semua pihak yang berkepentingan sehingga bisa menilai apakah perusahaan tersebut dalam kondisi sehat atau tidak. Prediksi kesulitan keuangan merupakan system peringatan dini bagi para pemangku kepentingan. Ketika perusahaan mengalami kesulitan keuangan ada beberapa perusahaaan yang mengalami kebangkrutan, namun ada juga yang tidak mengalami tahapan kebangkrutan (Ali Abusalah Elmabrok \& Ng, 2012).

Ada beberapa fase yang dialami pada tahap kebangkrutan yang pertama, kemampuan menghasilkan laba perusahaan akan menurun. Kedua, perusahaan akan mengalami ketidak cukupan kas untuk membayar hutang walaupun mungkin masih memiliki profitabilitas positif. Ketiga, terjadi kesulitan keuangan pada perusahaan. Keempat Perusahaan mengalami kebangkrutan.

Berdasarkan fenomena diatas maka tujuan penelitian yang diangkat yaitu untuk membandingkan tingkat akurasi prediksi model kesulitan keuangan menggunakan model altman z-score dan zmijewski pada bank bukopin dengan menggunakan data laporan keuangan tahun 2018, 2019 dan 2020. 


\section{METODE PENELITIAN}

Penelitian ini menggunakan metode dekskriptif kuantitatif dengan tujuan untuk menggambarkan fenomena yang terjadi. Objek dari penelitian ini yaitu Bank Bukopin. Populasi dari penelitian ini yaitu laporan keuangan tahunan Bank Bukopin Tbk, peneliti menggunakan teknik pengambilan sampel berdasarkan kriteria tertentu dengan mempertimbangkan ketersediaan data dan kemutahiran data sehingga menghasilkan sampel 3 tahun pengamatan yaitu laporan keuangan bank bukopin tahun 2018, 2019 dan 2020. Teknik analisis data yaitu dengan menghitung model prediksi Altman Z-score dan Zmijewski untuk tahun 2018,2019 dan 2020 serta melihat kriteria prediksi dari masing-masing tahun tersebut untuk kedua model.

Menurut (Altman, 2013) Model Altman Z-Score mengklasifikasikan perusahaan bank bukopin sebagai perusahaan non manufaktur maka menggunakan klasifikasi sebagai berikut, jika nilai Altman $z$-score $<1,1$ maka perusahaan dinyatakan berpotensi mengalami kebangkrutan. Selanjutnya jika nilai altman z-score berada pada rentang antara 1,1 - 2,6 maka diklasifikasikan sebagai area abu-abu tidak berpotensi bangkrut tetapi juga tidak sehat. Selanjutnya jika nilai skor altman $>$ 2,6 maka perusahaan diklasifikasikan sebagai sehat. Dikarenakan bank bukopin merupakan perusahaan bukan manufaktur maka model yang dikenal sebagai Revised Altman's Z-Score dengan fungsi diskriminan sebagai berikut.

$Z=6.56^{*} X 1+3.26^{*} X 2+6.72^{*} X 3+1.05^{*} X 4$

Dimana:

$\mathrm{X} 1=$ Modal kerja $/$ Aset total

$\mathrm{X} 2$ = Laba ditahan / Aset total

X3 = Laba sebelum bunga dan pajak / Aset total

X4 = Nilai buku ekuitas / Nilai buku hutang

Menurut (Zmijewski, 1984) Model ini ditemukan oleh Zmijeski melalui hasil riset yang dilakukan berulang-ulang selama 20 tahun pada tahun 1983. Model ini menghasilkan rumus sebagai berikut.

$X=-4,3-4,5 X 1+5,7 X 2-0,004 X 3$

Dimana :

$$
\begin{aligned}
& \text { X1 }=\text { ROA } \\
& \text { X2 }=\text { Rasio utang } \\
& \text { X3 = Rasion lancar }
\end{aligned}
$$

Kriteria pengambilan keputusan dari model prediksi ini yaitu jika nilai skor $>0$ maka perusahaan berpotensi mengalami kebangkrutan. Sebaliknya,jika nilai prediksi $<0$ maka perusahaan dikatakan sehat.

\section{HASIL DAN PEMBAHASAN}

Dalam menghitung model prediksi menggunakan model altman z-score penulis menggunakan data laporan posisi keuangan dana laporan laba rugi komprehensif tahun 2018, 2019 dan 2020. Langkah pertama yaitu mencari nilai X1 dengan cara menghitung selisih total aset dikurangai total liabilitas untuk mendapat modal kerja setelah itu dibahagi dengan total aset. Langkah kedua mencari X2 dengan cara membagi laba sebelum pajak dibahagi total aset bank bukopin. Langkah ketiga mencari nilai X3 dengan cara membagi nilai buku 
ekuitas dan nilai buku hutang bank bupokin dari tahun 2018 sampai 2020. Berikut hasil perhitungan model altman z-score.

Tabel 2. Perhitungan Model Prediksi Altman Z-Score Bank Bukopin Tahun 2018-2020

\begin{tabular}{llll}
\hline Altman Z-Score & 2018 & 2019 & 2020 \\
\hline Modal kerja & $8,595,437$ & $8,905,485$ & $8,466,442$ \\
Total asset & $95,643,923$ & $100,264,248$ & $79,938,578$ \\
x1 & 0,099 & 0,097 & 0,118 \\
Laba ditahan & $2,945,004$ & $3,200,834$ & $-1,408,501$ \\
Total asset & $95,643,923$ & $100,264,248$ & $79,938,578$ \\
x2 & 0,031 & 0,032 & 0,018 \\
Laba sebelum pajak & 216,335 & 133,794 & $-3,922,869$ \\
Total asset & $95,643,923$ & $100,264,248$ & $79,938,578$ \\
x3 & 0,002 & 0,001 & $(0,049)$ \\
Nilai buku ekuitas & $8,594,437$ & $8,905,485$ & $8,466,442$ \\
nilai buku hutang & $87,049,486$ & $91,358,763$ & $71,472,136$ \\
x4 & 0,099 & 0,097 & 0,118 \\
Z SCORE & 0,809 & 0,798 & 0,432 \\
Rata-Rata & & 0,6798 & \\
\hline
\end{tabular}

Sumber: Data Penelitian, 2020

Berdasarkan tabel diatas pada tahun 2018 perhitungan X1 sebesar 0.009, X2 sebesar 0.031 , X3 sebesar 0.002 dan X4 sebesar 0.099 dengan nilai Z Score yaitu 0.809 sehingga berdasarkan kriteria yang ditetapkan nilai $Z$ Score $<1$ maka perusahaan berada dalam kategori bankrut. Hal ini dikuatkan dengan perhitungan $Z$ Score pada tahun-tahun selanjutnya untuk tahun 2019 hasil perhitungan mendapati nilai 0.798 dan tahun 2020 mendapati nilai 0.432 , ketiga nilai $z$ score ini menggambarkan keadaan perusahaan termasuk dalam kategori Bangkrut karena memiliki nilai dibawah 1. Prediksi ini dikuatkan dengan kemampuan menghasilkan laba perusahaan yang semakin menurun sampai mangalami kerugian di tahun 2020 ini dilihat dari laba sebelum pajak perusahaan yang terus menurun dari tahun 2018 sampai 2020. Kriteria kategori bangkrut menjelaskan bahwa dalam dua sampai tiga tahun mendatang perusahaan akan berpotensi mengalami kebangkrutan.

Tabel 3. Perhitungan Model Prediksi Zmijewski Bank Bukopin Tahun 20182020

\begin{tabular}{llll}
\hline Zmijewski & 2018 & 2019 & 2020 \\
\hline Laba bersih & 379,087 & 311,048 & $-3,041,791$ \\
Total aset & $95,643,923$ & $100,264,248$ & $79,938,578$ \\
X1 & 0,004 & 0,003 & $(0,038)$ \\
Total utang & $87,049,486$ & $91,358,763$ & $71,472,136$ \\
Total aset & $95,643,923$ & $100,264,248$ & $79,938,578$ \\
X2 & 0,910 & 0,911 & 0,894 \\
Aset lancar & $85,349,356$ & $87,668,576$ & $69,019,702$ \\
Utang lancar & $81,309,649$ & $86,642,858$ & $64,184,977$ \\
X3 & 1,050 & 1,012 & 1,075 \\
Zmijewski score & 0,8658 & 0,8757 & 0,9632 \\
rata-rata & & 0,9016 & \\
\hline
\end{tabular}

Sumber: Data Penelitian, 2020 
Selanjutnya dalam menghitung model prediksi menggunakan model Zmijewski penulis menggunakan data laporan posisi keuangan dana laporan laba rugi komprehensif tahun 2018, 2019 dan 2020. Langkah pertama yaitu mencari nilai X1 dengan membandingkan Laba komprehesif perusahaan dengan total aset, selanjutnya dengan mencari $\mathrm{X} 2$ dengan cara membagi total utang dengan total aset dan terakhir mencari X3 dengan cara membagi total aset lancar dengan total utang lancar. Berikut perhitungan model Zmijewski bank bukopin tahun 2018 sampai 2020.

Berdasarkan tabel diatas pada tahun 2018 perhitungan X1 sebesar 0.004, X2 sebesar 0.91, X3 sebesar 1.005 dan nilai $X$ score sebesar 0.8658 , sehingga berdasarkan kriteria yang ditetapkan nilai $X$ Score $>0$ maka perusahaan berada dalam kategori berpotensi bankrut. Hal ini dikuatkan dengan perhitungan $X$ Score pada tahun-tahun selanjutnya untuk tahun 2019 hasil perhitungan mendapati nilai 0.8757 dan tahun 2020 mendapati nilai 0.9632 , ketiga nilai $X$ score ini menggambarkan keadaan perusahaan termasuk dalam kategori Bangkrut karena memiliki nilai diatas 0. Prediksi ini dikuatkan dengan kemampuan menghasilkan laba perusahaan yang semakin menurun sampai mangalami kerugian di tahun 2020 ini dilihat dari laba komprehensif perusahaan yang terus menurun dari tahun 2018 sampai 2020.

\section{SIMPULAN}

Model prediksi kemampuan keungan menggunakan Model Altman Z-Score dan Model Zmijewski sama-sama menghasilkan nilai prediksi yang sama yaitu bank bukopin dalam 2 sampai 3 tahun kedepan akan berpotensi menghadapi kebangkrutan. Penelitian ini menyarankan bahwa para pengambil keputusan terhadap bank bukopin agar hati-hati dalam mengambil keputusan yang berkaitan dengan investasi, kredit ataupun lainnya. Untuk bank bukopin sendiri melalui penelitian ini diharapkan agar segera meningkatkan kinerja mereka. Penelitian ini hanya membandingkan dua model kesulitan keuangan dalam satu perusahaan sehingga disarankan pada penelitian selanjutnya menggunakan model kesulitan keuangan yang lain dengan sampel yang lebih banyak beserta tambahan analisis statistik yang mendukung perbandingan tingkat akurasi.

\section{REFERENSI}

Ali Abusalah Elmabrok, M., \& Ng, K. (2012). Using Altman's Model and Current Ratio to Assess the Financial Status of Companies Quoted In the Malaysian Stock Exchange. International Journal of Scientific and Research Publications, 2(7), 1-11.

Altman, E. I. (2013). Predicting financial distress of companies: Revisiting the ZScore and ZETA ${ }^{\circledR}$ models. In Handbook of Research Methods and Applications in Empirical Finance. https://doi.org/10.4337/9780857936097.00027

Ashraf, S., G. S. Félix, E., \& Serrasqueiro, Z. (2019). Do Traditional Financial Distress Prediction Models Predict the Early Warning Signs of Financial Distress? Journal of Risk and Financial Management. https://doi.org/10.3390/jrfm12020055

Asmoro, A. (2020). Banking Challenges and Readiness to Face the New Normal. https://www.its.ac.id/drpm/wp- 
content/ uploads/sites/71/2020/06/200611-New-Normal-dan-TantanganPerbankan-ITS.pdf

Ayu Damayanti, N., Prasetyaningtyas Jurusan Manajemen, S., Kunci, K., \& ZScore, A. (2011). Analisis Perbandingan Model Prediksi Kebangkrutan ... Analisis Perbandingan Model Prediksi Kebangkrutan Altman Z-Score dan Zmijewski di BEI Periode 2011-2015 (Comparative Analysis of Altman Z-Score and Zmijewski Bankruptcy Prediction Models in BEI Period. VI(1), 171-174.

Brigham, E. F., \& Daves, P. R. (2007). Capital Budgeting: Decision Criteria. In Intermediate Financial management. https://doi.org/10.1016/08908389(89)90100-5

Covid-, P. (2020). Kinerja Perbankan Era Proyeksi Pertumbuhan Ekonomi Global dan Indonesia.

Geng, R., Bose, I., \& Chen, X. (2015). Prediction of financial distress: An empirical study of listed Chinese companies using data mining. European Journal of Operational Research. https://doi.org/10.1016/j.ejor.2014.08.016

Jayanti, Q., \& Rustiana. (2015). Analisis Tingkat Akurasi Model-Model Prediksi Kebangkrutan untuk Memprediksi Voluntary Auditor Switching (Studi Pada Perusahaan Manufaktur Yang Terdaftar di BEI). Modus, 27(2), 87-108.

Kansal, Ajay Kr; Shashank, S. (2019). A Methodological Review of Financial. 4th International Conference on Advances in Management E Digital Sciences, 1968, 294-301.

Muliati, N. K. (2020). Pengaruh Perekonomian Indonesia di Berbagai Sektor Akibat Corona Virus Disease 2019 (Covid-19). Widya Akuntansi Dan Keuangan, 2(2), 78-86. https:/ / doi.org/10.32795/widyaakuntansi.v2i2.874

Permana, R. K., Ahmar, N., \& Djadang, S. (2017). Prediksi Financial Distress Pada Perusahaan Manufaktur Di Bursa Efek Indonesia. Esensi: Jurnal Bisnis Dan Manajemen. https:// doi.org/10.15408/ess.v7i2.4797

Plat, H. D., \& Plat, M. B. (2002). Predicting Corporate Financial Distress: Reflections on Choice-Based Sample Bias. Journal of Economics and Finance.

Prasetianingtias, E., \& Kusumowati, D. (2019). Analisis Perbandingan Model Altman, Grover, Zmijewski Dan Springate Sebagai Prediksi Financial Distress. Jurnal Akuntansi Dan Perpajakan, 5(1), 1-3. https://doi.org/10.26905/ap.v5i1.3072

Sajjan, P. R. (2016). Predicting Bankruptcy of Selected Firms By Applying Altman' s Z-Score Model. International Journal of Research-Granthaalayah.

Suparningsih, B., \& Chaeriah, E. S. (2019). Perbandingan Prediksi Kebangkrutan Menggunakan Model Altman Modifikasi, Springate, Zmijewski Dan Grover Pt Ratu Prabu Energi Tbk. Jurnal Manajemen Bisnis Krisnadwipayana, 7(3). https:/ / doi.org/10.35137/jmbk.v7i3.346

Suryawardani, B. (2015). Analisis Perbandingan Kemampuan Prediksi Kebangkrutan Antara Analisis Altman, Analisis Ohlson Dan Analisis Zmijewski Pada Sektor Industri Tekstil Yang Go Public Di Bursa Efek Indonesia Periode 2008-2012. Ecodemica.

Taufik, \& Ayuningtyas, E. A. (2020). Dampak Pandemi Covid-19 Terhadap Bisnis Dan ( the Impact of Covid-19 Pandemic on Business and Online. Jurnal Pengembangan Wiraswasta, 22(01), 21-32. https://doi.org/10.33370/jpw.v22i1389 
Udayana, E. A. U., Kebangkrutan, P., Model, D., Made, N., Dwi, E., \& Sari, M. M. R. (2013). Analisis Prediksi Kebangkrutan Dengan Model Grover, Altman Z-Score, Springate Dan Zmijewski Pada Perusahaan Food and Beverage Di Bei. E-Jurnal Akuntansi, 5(2), 417-435.

Utami, D., \& Kawulur, H. R. (2020). Analysis of Bankruptcy Prediction by Altman Z-Score Modification (Study at PT BPR Primaesa Sejahtera Kota Manado). International Journal of Applied Business and International Management, 8-15. https:// doi.org/10.32535/ijabim.v0i0.871

Zmijewski, M. E. (1984). Methodological Issues Related to the Estimation of Financial Distress Prediction Models. Journal of Accounting Research. https://doi.org/10.2307/2490859 